\title{
Health Service Delivery
}

\section{Environmental Health Services}

MUKUNDAN SUGUNAN PILLAY AND DEBBIE S IRU

\subsection{Introduction}

The protection and management of the natural and built environment and monitoring its relation to and impact on health are important components of any country's health system. The ever-expanding global population and increasing urbanization place a strain on the environment and create new risks and exposures that exacerbate health problems. The first line of defence in disease prevention is controlling the physical, chemical and biological agents in the environment that have the potential to affect populations. Thus, every aspect of the environment that impacts on health falls within the scope of environmental health services (EHS). Clean water, safe disposal of solid waste and wastewater, vector and rodent control, air pollution control, food quality control and climate change are just some examples. In this chapter, we focus on providing a broad overview of the evolution of EHS in Malaysia as part of the overall health system.

\subsection{Overview of EHS and Its Evolution in Malaysia}

In the 1960 s, after independence, $70 \%$ of the population was poor and resided in rural areas (see Chapter 3). Limited water accessibility and communicable diseases were major problems, which were addressed by the Rural Environmental Sanitation Programme (RESP), an integral component of the Rural Health Services (Suleiman \& Jegathesan, n.d.). Highly effective community mobilization by allied environmental health officers and technical expertise from engineers trained in public health are credited as two success factors of the RESP, which achieved high levels of coverage and drastic reduction of the disease burden from waterborne diseases. 
With increasing economic development, more than $70 \%$ of the population moved to urban areas, life expectancy increased, and there was a decline in infant mortality rates and incidence of communicable diseases (see Chapter 3) (Ministry of Health Malaysia, 19882017). However, population growth, increasing urbanization and industrialization introduced other environmental hazards, creating the need to address a wider range of environmental health issues such as sewerage, water quality, solid and hazardous waste, and radiation protection.

EHS in Malaysia began in an organized and structured manner with the establishment of the Environmental Health Engineering Programme in the Ministry of Health $(\mathrm{MoH})$, pioneered by engineers seconded from the Public Works Department (PWD) in the 1970s. This pool of engineers, often assisted by sanitary engineers from the World Health Organization (WHO), went on to strengthen the EHS as an integral part of the MoH's public health programme.

As the Constitution of Malaysia apportions responsibility for health to the federal government, and water supply and urban sanitation to state and local governments, the responsibility for managing EHS was split among different government agencies (see Chapter 12).

To provide leadership and the relevant authority, some public health engineers were seconded from the $\mathrm{MoH}$ to some of these departments. Thus EHS in Malaysia grew primarily because of the leadership and governance role the $\mathrm{MoH}$ took. EHS established an organizational structure and staffed it with trained personnel while at the same time empowering the organizational units with the required funding. The initial batch of public health engineers provided the leadership on the ground to support the health inspectorate and health officers. Human resources training and development were crucial to achieving success. Environmental health was introduced into postgraduate public health programmes. Engineers who had training in public health helped to upgrade the training of health inspectors and health overseers. The upgraded three-year course for health inspectors (see Chapter 8) included aspects of newer technologies in wastewater treatment, water treatment and waste disposal. Also, environmental health was included in the training of microbiologists and biochemists. Expertise was shared with other ministries and departments. The WHO contributed by establishing the Centre for the Promotion of Environmental Planning and Applied Studies (PEPAS), which conducted valuable 
research and training programmes that in turn led to policy and programme formulation such as the National Solid Waste Management Strategy (WHO Western Pacific Region, 1977). Introducing health impact assessment (HIA) to other agencies for development projects was a concerted effort using many existing channels available at the state and federal government levels (Hashim \& Hashim, 2009).

\subsubsection{Examples of Malaysia's EHS Programmes}

Some of the main environmental health programmes that were developed successfully are described in this section.

\subsubsection{Rural Environmental Sanitation Programme (RESP)}

Concerns about the quality of water supply and sanitation led to an environmental survey of Peninsular Malaysia in 1968. It revealed that only $3.6 \%$ of the population had piped water, while $85.3 \%$ used water from unprotected wells and $11.1 \%$ from untreated surface water (Pillay et al., n.d.). As a result, an environmental sanitation pilot project was carried out. The pilot project indicated that a national environmental health programme needed to have four basic elements to succeed: community participation, health education, appropriate technology and training. The initial efforts of EHS were directed to rural areas of the country that lacked safe water supply and sanitation and were plagued by waterborne diseases (Suleiman \& Jegathesan, n.d.). The national programme was successful in increasing coverage of the rural population of safe water supply to $68.6 \%$ and sanitary latrines to $72.5 \%$ in 1987 (Ministry of Health Malaysia, 1989). This coverage reached 93.5\% for safe water supply and $98.2 \%$ for sanitary latrines in 2000 (Ministry of Health Malaysia, 2002). The $\mathrm{MoH}$ had contributed to $22.2 \%$ of the water supply for rural communities. The $\mathrm{MoH}$ provided a high percentage of water supply in states such as Sarawak (62.3\%), Sabah (43.5\%), Kelantan (32.5\%) and Terengganu (30.4\%) (Pillay et al., n.d.).

This programme was not only a paradigm shift, with the $\mathrm{MoH}$ taking on a function that was traditionally that of state governments and the PWD, it also became an important programme under the $\mathrm{MoH}$ public health programmes. It complemented the other programmes, such as communicable disease control, vector hygiene, food quality control and others, and was implemented in all states (Ministry of Health Malaysia, 1988). The Environmental Health Engineering Unit 
Box 7.1 System observations: cross-boundary problems

One of the challenges in the application of systems thinking is that the actual system surrounding a particular problem often does not correspond to disciplinary or organizational structures. Therefore, solutions to these problems are often partial, with partial results. Indeed, while the 'social and environmental determinants of health' is a well-known concept, it largely remains on the periphery of health systems. A whole-system approach towards environmental health requires interfacing with non-health sectors as well as re-thinking the responsibilities and functions of the health system. The expansion of the $\mathrm{MoH}$ to create an engineering department and take on the task of rural water and sanitation is an excellent example of such cross-boundary work. Future advances in tackling non-communicable diseases are likely to require such re-thinking of what health services look like.

grew and was later expanded with the recruitment of more public health engineers and health inspectors. The unit provided the needed policies, technical guidance and training, and it also monitored budget allocations. Initially, public health engineers were stationed in critical states such as Kedah, Perak, Pahang, Terengganu and Kelantan, but they are now present in every state nationwide. Health inspectors were trained in appropriate technologies for rural water supply and sanitation. RESP, later called the BAKAS (Bekalan Air dan Kebersihan Alam Sekeliling) or Water Supply and Environmental Sanitation Programme, clearly demonstrated the close interaction between the different levels of government. The federal government provided the funds and technical advisory services while the state governments provided the needed managerial support through the district levels right up to the village action committees (Suleiman \& Jegathesan, n.d.). This was a key success factor, as was the people's involvement through community participation (see Case Study 7.1 for more details).

\subsubsection{National Drinking Water Quality Surveillance Programme (NDWQSP)}

Having succeeded in the BAKAS programme, the $\mathrm{MoH}$ engineering unit was entrusted with monitoring the quality of urban water supplies. 
This decision was made following a survey in 1983 that attributed the outbreak of diseases to poorly operated water supply systems. This programme, known as the National Drinking Water Quality Surveillance Programme (NDWQSP), had the objective of improving the standard of health by ensuring the safety and acceptability of public water supply systems (Suleiman \& Jegathesan, n.d.). The components of the programme included monitoring, sanitary surveys, data processing and evaluation, remedial action and institutional examination such as evaluating the capacity of the water supply agency to perform its functions. Under the programme, all public water supplies were monitored, and samples were sent to the Department of Chemistry (DOC) for bacteriological and chemical analysis (Pillay \& Sinha, n.d.). The relevant water authority was required to take immediate action if there were any violations of the standards set by the $\mathrm{MoH}$. A quality assurance programme (QAP) was formulated in 1993 to strengthen the effectiveness of the programme (Suleiman \& Jegathesan, n.d.). By 2001, the percentage of water samples that met the national standards of bacteriological quality, residual chlorine and turbidity was $98 \%$, $96 \%$ and $96 \%$, respectively (Pillay \& Sinha, n.d.).

Significant co-operation was established between the state governments, water authorities and relevant agencies such as the DOC, the Department of Environment (DOE) and the federal Drainage and Irrigation Department as well as local authorities. The reports generated under this programme were presented at state- and federal-level meetings and critically examined by many agencies. The training of water operators and health inspectorate staff and public health engineers, coupled with inter-departmental co-operation, were key success factors of this programme. Due to the limited capacity of the DOC, the $\mathrm{MoH}$ also developed its water testing capabilities (Ministry of Health Malaysia, 1988) by purchasing field test kits and training the health inspectorate staff and public health engineers on their use.

The leadership and promotional role of the $\mathrm{MoH}$ was important in the absence of legislation. The Safe Drinking Water Act was drafted in the 1980s but never came into force for numerous reasons. However, since then, the National Water Services Commission (SPAN) has been formed to address some of the constitutional problems, such as division of responsibility and authority between federal and state government, and the Water Services Industry Act 655 was formulated and enforced in 2008 (National Water Services Commission, 2019). 


\subsubsection{Urban Sanitation}

The role played by public health engineers at the state level was recognized as crucial, and over time they played a key role in advising state governments of the sad state of urban sanitation. Together with the Economic Planning Unit (EPU) of the Prime Minister's Department, the $\mathrm{MoH}$ engineering unit initiated Master Plan Studies on sewerage and drainage in many towns (Economic Planning Unit, 1981). Such studies identified a grave concern: bucket latrines were widely used in urban centres. Eliminating bucket latrines became a priority, together with studies on suitable sewerage systems for larger towns.

Other than bucket latrines, individual septic tanks were the predominant disposal system. Substantial funds were needed to convert centralized sewerage systems and this would, therefore, take a long time. The $\mathrm{MoH}$ adopted an incremental strategy by promoting the use of centralized sewerage systems as opposed to individual septic tanks (Ujang, 2006). All new development projects were directed to follow the guidelines developed by the $\mathrm{MoH}$ and to instal centralized sewerage systems with treatment plants such as oxidation ponds. There was no legislation at that time; this was purely based on the MoH's insistence and promotion through its expanded numbers of well-trained public health engineers (Ujang, 2006).

Similar efforts were made in solid waste management. All urban centres had poor waste management systems. Open burning was rampant. Crude landfills were the norm. With support from the WHO, the $\mathrm{MoH}$ initiated national forums to develop strategic plans for waste management. Through the environmental health engineering programme, the $\mathrm{MoH}$ also provided support to the Prime Minister's Department and the Ministry of Housing and Local Government (MHLG) in matters related to sewerage, urban waste management, urban drainage and urban environmental management (Ujang, 2006; Ministry of Housing and Local Government, Malaysia, 2005).

In 1980, a special technical unit with engineers seconded from the $\mathrm{MoH}$ was formed to serve as the technical arm of the Local Government Department of the MHLG. This unit provided technical advisory services to all local authorities and state governments. Numerous studies were undertaken, and guidelines were developed. A major achievement was the total elimination of the bucket latrine system. Policies for urban sewerage systems became entrenched in local development plans, and efforts moved towards the formulation of laws on sewerage and waste management (Ujang, 2006). This then 
progressed to the privatization of both the national sewerage service and the municipal waste management services. The enactment of these laws and privatization were unprecedented moves by the federal government to take over services traditionally performed by state and local governments. It paid off handsomely, as this led to the systematic development of these two services throughout the country (Japan International Cooperation Agency (JICA), Malaysia Office, 1999).

The privatization of sewerage services was undertaken through the enactment of the Sewerage Services Act, which allowed the federal government to take over the responsibility for sewerage services, which was a traditional function of local authorities. A national sewerage company called Indah Water Konsortium (IWK) was established (Japan Sanitation Consortium, 2011). IWK took over all sewerage assets from local authorities and moved to upgrade and maintain these systems to acceptable standards by ensuring all domestic wastewater was adequately treated before discharging to surface water (Sewerage Services Department, Ministry of Housing and Local Government, 2001). Another significant move was the creation of the Sewerage Services Department (SSD) to regulate sewerage services, and this was staffed with engineers seconded from the MoH (Ujang, 2006).

\subsubsection{Clinical Waste Management}

Recognizing the hazardous nature of clinical waste generated in healthcare settings, the Engineering Division of the $\mathrm{MoH}$ undertook a national survey that highlighted the poor conditions in the handling, storage, transportation and disposal of clinical waste. The division went on to issue guidelines for the management of clinical and related waste in hospitals and healthcare establishments, followed by training for selected hospital personnel (Ministry of Health Malaysia, 1991). The gaps identified in the system were addressed by outsourcing clinical waste management to hospital support services. The rapid progress under this strategy was self-evident and is further outlined in Case Study 7.2 at the end of this chapter.

\subsubsection{Air Pollution}

Air pollution in Malaysia is generally at a low level except for sporadic incidents of haze during certain periods of the year. Maintaining good air quality sustainably throughout the year will drastically reduce the burden on the healthcare system. For this purpose, Malaysia built inter- 
departmental co-operation, involving agencies such as the DOE, the $\mathrm{MoH}$, the Ministry of Transport, the Ministry of Natural Resources and Environment, the Meteorology Department and the Ministry of Foreign Affairs. The private sector was also mobilized by outsourcing air quality monitoring to a private company, Alam Sekitar Malaysian Sdn Bhd (ASMA), which has fifty-two monitoring stations throughout the country (Sahani et al., 2016).

As mentioned earlier, public health engineers were seconded from the $\mathrm{MoH}$ to the DOE, and they contributed to the formulation of the Environmental Quality Act 1974 (EQA) and its subsidiary regulations, which included among others the Clean Air Regulations. The $\mathrm{MoH}$ was a member when the Environmental Quality Council was launched in 1973, and its membership was subsequently formalized in the EQA. The council is responsible for advising the Minister of the then Ministry of Science, Technology and the Environment, now known as the Ministry of Natural Resources and Environment, regarding environmental matters, and this includes, among other things, air pollution (The Commissioner of Law Revision Malaysia, 2006).

The $\mathrm{MoH}$ also contributed the development of guidelines on indoor air quality (IAQ), which is under the purview of the Department of Occupational Safety and Health (DOSH), and continues to play a critical role in providing health advisory notices via news media, their website and so on. The MoH has also developed several guidelines on IAQ for healthcare settings and is training a pool of engineers to be certified by DOSH as indoor air quality assessors. To kickstart its IAQ programme, the $\mathrm{MoH}$ is currently focusing on sampling and monitoring air quality in its premises (Ministry of Health Malaysia, 1992).

\subsubsection{The National Environmental Health Action Plan (NEHAP)}

The NEHAP is a set of strategies jointly developed by relevant agencies and selected non-governmental organizations (NGOs) for improving environmental health in the country by specifying the roles and responsibilities of all parties. The WHO has encouraged all countries to embark on developing and implementing NEHAPs. The Malaysian Cabinet endorsed the NEHAP as a government policy in December 2012, and implementation is underway, with state governments assuming responsibility for formulating and implementing their respective State Environmental Health Action Plans (SEHAPs) (Tuan Mat, 2016). Some states, such as Sabah, Pahang, Perak and Melaka, 
have already started finalizing their SEHAPs, and the momentum is growing among other states (Tuan Mat, 2016). States' adoption of the SEHAPs will be followed by the development of Local Environmental Health Action Plans (LEHAPs).

In order to be effective, NEHAP has to be given priority at all levels, including full participation and commitment from relevant agencies and NGOs, appropriate resource allocation and the enforcement of laws and regulations. The Engineering Services Division of the $\mathrm{MoH}$ facilitates and monitors the process by assuming the role of secretariat for the NEHAP, its steering committee, technical committee and the thematic working groups (TWGs). Eleven TWGs address various areas of concern such as vector-borne diseases, urban drainage and air quality as well as emerging issues such as climate change (National Environmental Health Action Plan, n.d.; Tuan Mat, 2016). The Division is also working with the Malaysian Space Agency (MYSA), formerly known as the Malaysian Remote Sensing Agency, to develop a geospatial risk map. This will be an invaluable tool for pre-empting adverse environmental health incidents.

Health impact assessments (HIA) have been incorporated as part of the Environmental Impact Assessment (EIA) process. The MoH undertakes the review of the components of EIA related to environmental HIA. Its importance is further emphasized by its inclusion as a TWG under NEHAP.

\subsubsection{Factors Contributing to Success}

The MoH rightly invested in environmental health programmes early on, which is believed to have significantly contributed to the country's elevated health status. Other than investment, the hallmarks of the developmental process included leadership from the $\mathrm{MoH}$ in initiating and sustaining inter-agency collaboration and co-operation, human resource development and selective organizational strengthening, enactment of legislation and development of guidelines, and strategic involvement of the private sector while the public sector retained responsibility for policy and oversight.

Inter-departmental co-operation/organizational shift of responsibilities: From the beginning, the $\mathrm{MoH}$ recognized that interdepartmental collaboration was vital, given that so many aspects of the 
human environment and activities have an impact on health. The MoH adopted two distinct modalities. In the case of rural water supply, the $\mathrm{MoH}$ took over the role that had traditionally rested with state governments and the PWD. In other cases, the MoH took the lead in spearheading the required changes and subsequently handing over authority to the relevant government departments (see Section 7.2.1.3). Spearheading change involved building technical and managerial capacity in other organizations and providing technical guidance and advice in various forms, including research, guidelines, formulation of legislation and creation of appropriate infrastructural capacity, for example, for chemical testing. However, the $\mathrm{MoH}$ maintained its responsibility for health by insisting that health matters be referred to it where relevant, for example, HIA in EIA for development projects. It continues to provide advice via the Environmental Quality Council (The Commissioner of Law Revision Malaysia, 2006).

Building human resource capacity: Initially the $\mathrm{MoH}$ had to build its own capacity for environmental health. This was done by acquiring two engineers seconded from the PWD in the 1970s. They went on to develop a pool of public health engineers, some of whom were subsequently seconded to the DOE, MHLG, SSD, Solid Waste Department (SWD) and so on to spearhead change in those agencies and to help them recognize that their responsibilities encompassed not merely engineering perspectives but needed to expand to include environmental health perspectives. An outstanding outcome of this initiative is the formulation of the EQA and its subsidiary regulations, which provided for licensing and establishing standards for preventing, abating and controlling environmental pollution primarily from industries and shipping. Other outcomes include the enactment of the Sewerage Services Act 1993 and the Solid Waste and Public Cleansing Acts 2007.

Community participation: In rural areas in particular, EHS succeeded by incorporating community involvement and participation in all programmes. Community participation helped to reduce the cost of projects and resulted in speedy implementation because the community leaders were motivated and wanted results quickly. There was shared ownership, and communities maintained the sanitation and water systems. The leadership structure in villages, such as the village action committee established under the government's integrated rural development programme, helped with proper project planning and 
implementation. The series of health education campaigns by the district health offices also helped to mobilize the community. The support of local politicians further boosted effective community participation (Suleiman \& Jegathesan, n.d.).

Private sector involvement: The private sector complemented the role of the public sector in several ways. In the early years, the private sector was engaged to develop plastic pour-flush latrines for the RESP and later in developing Malaysian home-grown plastic hand pumps, water tanks and other accessories. The mass production of these essential items brought the cost to affordable ranges. Later, when the national privatization policy was introduced, the private sector played greater roles (Japan International Cooperation Agency (JICA), Malaysia Office, 1999). The public sector outsourced to the private sector the programmes for national sewerage development, including the urban solid waste management programme, clinical waste management and the monitoring of air quality throughout the country. The privatization policy helped to strengthen and further develop EHS in a systematic manner, as it allowed the government to focus on its primary functions of policy and oversight while the private sector delivered services. Under the privatization policy, the required funding mechanisms were also put in place with revenue generation opportunities. Various laws and regulations were enacted to delineate responsibilities among the various agencies and to set standards for service delivery (Japan International Cooperation Agency (JICA), Malaysia Office, 1999).

With outsourcing, the oversight function for ensuring that the private sector achieved good outcomes still rested and continues to rest with the government and its agencies. For example, when the clinical waste management service was privatized, the $\mathrm{MoH}$ engaged specialists to monitor the performance of the private concessionaires (Suleiman \& Jegathesan, n.d.) against standards and guidelines and even introduced a fee deduction mechanism for non-performance or poor performance of the service. Similarly, when sewerage service was privatized, a new Sewerage Services Department was created to enforce the legislation. The government had to create standards, codes of practices and guidelines as well. Privatization does not absolve the government of its responsibilities.

Outsourcing has worked well in Malaysia and has fast-tracked many EHS programmes. Other countries seeking to privatize 
should carefully consider the selection of the privatization model and take into consideration that once a service is privatized, it is difficult to reverse it.

\subsection{Key Messages from Malaysia’s Experience}

\subsubsection{What Went Well?}

- Basic rural interventions for water and human waste disposal used

- simple technology,

- strong community participation, and

$\circ$ allied health staff delivered them effectively using established community structures.

- Higher technological interventions requiring appropriate competencies were

○ possible for concentrated urban populations (water, solid and liquid waste management);

- needed for complex issues (clinical waste, radiation);

$\circ$ under the jurisdiction of authorities outside the health sector and needed inter-sectoral co-ordination.

- The health sector successfully

- acquired and empowered staff with the appropriate competencies;

$\circ$ provided leadership and assisted, then mentored, other agencies to develop the required competencies and exercise their powers through governance, outsourcing and oversight;

$\circ$ mobilized private sector finance through outsourcing; and

$\circ$ gained experience and expertise in outsourcing.

\subsubsection{What Did Not Go So Well?}

Several issues outside the jurisdiction of the health sector remain problematic, for example, occupational health, air pollution and road traffic accidents.

\subsubsection{Trends and Challenges}

Climate change is expected to increase the frequency and severity of conditions that will stretch the capacity of the health system 


\section{References}

The Commissioner of Law Revision Malaysia. (2006). Act 127: Environmental Quality Act 1974. Laws of Malaysia. Kuala Lumpur: Commissioner of Law Revision Malaysia.

Economic Planning Unit (EPU). (1981). Master Plan and Feasibility Study for Sewerage and Drainage Systems in Kuantan and Kuantan Port Inception/ Progress Report. Kuala Lumpur: Minconsult.

Federation of Malaysia. (n.d.). Report of the Medical Department 1960. Kuala Lumpur.

Hashim, J. H. and Hashim, Z. (2009). Guidance Document on Health Impact Assessment (HIA) in Environmental Impact Assessment (EIA). Putrajaya: Department of Environment Malaysia.

Japan International Cooperation Agency (JICA), Malaysia Office. (1999). Privatisation of Water, Sanitation and Environment-Related Services in Malaysia. Kuala Lumpur: Japan International Cooperation Agency, Malaysia Office.

Japan Sanitation Consortium (JSC). (2011). Country Sanitation Assessment in Malaysia. Tokyo: Japan Sanitation Consortium.

Ministry of Health Malaysia. (1988). Annual Report 1986. Kuala Lumpur: Ministry of Health Malaysia.

Ministry of Health Malaysia. (1989). Annual Report 1987. Kuala Lumpur: Ministry of Health Malaysia.

Ministry of Health Malaysia. (1990). Annual Report 1988. Kuala Lumpur: Ministry of Health Malaysia.

Ministry of Health Malaysia. (1991). Annual Report 1989. Kuala Lumpur: Ministry of Health Malaysia.

Ministry of Health Malaysia. (1992). Annual Report 1990. Kuala Lumpur: Ministry of Health Malaysia.

Ministry of Health Malaysia. (1993). Annual Report 1991. Kuala Lumpur: Ministry of Health Malaysia.

Ministry of Health Malaysia. (1997). Annual Report 1995. Kuala Lumpur: Ministry of Health Malaysia.

Ministry of Health Malaysia. (2002). Annual Report 2000. Kuala Lumpur: Ministry of Health Malaysia.

Ministry of Health Malaysia. (2003). Annual Report 2001. Kuala Lumpur: Ministry of Health Malaysia.

Ministry of Health Malaysia. (2017). Annual Report 2015. Putrajaya: Ministry of Health Malaysia.

Ministry of Housing and Local Government, Malaysia. (2005). National Strategic Plan for Solid Waste Management. Kuala Lumpur: Ministry of Housing and Local Government Malaysia. 
National Environmental Health Action Plan (n.d.). Areas of Concern. Online report. http://nehapmalaysia.moh.gov.my/about-nehap/areas-of-concern

National Water Services Commission. (2019). The Commission's Role: National Water Services Commission. Online webpage. www .span.gov.my/article/view/the-commission-s-role

Pillay, M. S., Sinha, K. and Talha, M. Z. M. (2003). Water quality and health. Environmental Health Focus: Managing the Environment for Health in the Asia Pacific, 1(2), 8-11.

Pillay, M. S., Sinha, I. K. and Talha, M. Z. M. (n.d.). Providing Reliable Drinking Water Supply to Remote Communities in Malaysia. Putrajaya: Ministry of Health Malaysia.

Sahani, M., Khan, M. F., Mahiyuddin, W. R. W., Latif, M. T., Ng, C. F. S, Yussof, M. F. et al. (2016). Air pollution and health in Malaysia: case studies from Asia. In D.-C. Shin, ed., Hazardous Air Pollutants. Boca Raton, FL: CRP Press, pp. 97-114.

Sewerage Services Department, Ministry of Housing and Local Government. (2001). Sewerage Services Report. Kuala Lumpur: Ministry of Housing and Local Government.

Suleiman, A. B. and Jegathesan, M. (eds.). (n.d.). Health in Malaysia: Achievements and Challenges. Ministry of Health Malaysia.

Tuan Mat, E. A. (2016). Significance of NEHAP Malaysia. Paper presented at Persidangan NEHAP Malaysia 2016, PICC Putrajaya.

Ujang, Z. (2006). Strategy and planning of sewerage infrastructures for developing countries: experience of Malaysia. In Z. Ujang and M. Henze, eds., Municipal Wastewater Management in Developing Countries. London: IWA, pp. 46-69.

WHO Western Pacific Region. (1977). Western Pacific Regional Centre for the Promotion of Environmental Planning and Applied Studies (PEPAS) (Resolution). Manila: WHO Regional Office for the Western Pacific. 


\section{System Analysis Case Study 7.1: Rural Water Supply and} Sanitation

Mukundan Sugunan Pillay, Debbie Siru and David T. Tan

\section{Introduction}

Adequate water supply and sanitation are basic requirements for ensuring safety from waterborne diseases such as cholera and typhoid. A gap in adequate water supply for rural communities caused major disease outbreaks among this population. In response, the MoH Malaysia launched a major nationwide initiative, the Rural Environmental Sanitation Programme (RESP), which resulted in the reduction of waterborne diseases. The initiative relied on introducing engineering principles and practices coupled with health education and community participation to attain success. This case study elaborates on the programme in further detail.

\section{The Problem}

The Malaysian government prioritized water and sanitation infrastructure as a health and development strategy to curb the spread of waterborne diseases. This function was the traditional role of the state governments and the federal Public Works Department (PWD). However, limitations in personnel and finance meant that the PWD adopted a big-project, cost-efficiency approach, focusing on population centres and working outwards towards semi-urban areas. They were not equipped to deliver smaller, intermediate solutions to rural areas because their workforce was small and lacked connections to rural communities.

Thus there were long delays before rural communities could be served. Indeed, a landmark survey in 1968 by the MoH showed that only $3.6 \%$ of the rural population received a treated piped water supply, with $85.3 \%$ depending on water supply from unprotected wells and $11.1 \%$ relying on untreated surface waters (Suleiman \& Jegathesan, n.d.). There were many outbreaks of waterborne disease in rural areas. The PWD was unable to respond to these negative health outcomes (Figure 7-A, B1 loop dotted line). 


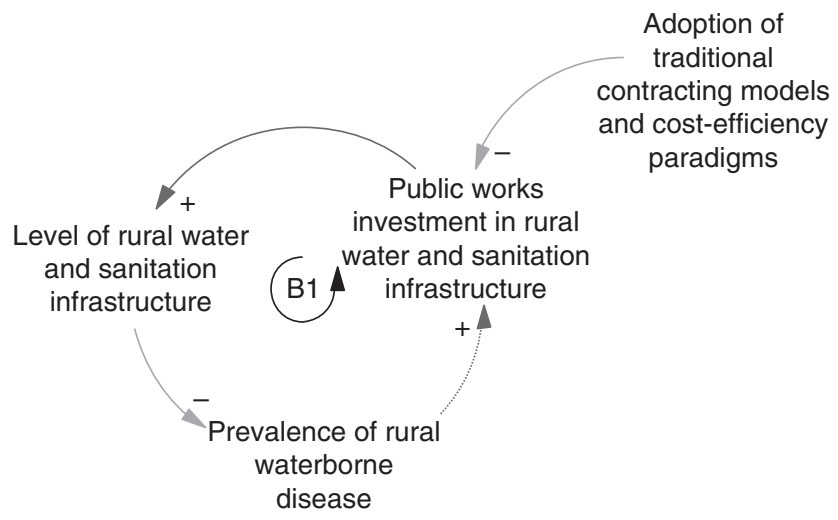

Figure 7-A The PWD strategy for expanding the water and sanitation network was unable to respond to rural disease burdens in a timely manner.

The $\mathrm{MoH}$ attempted to address the spread of waterborne disease through educational efforts on sanitation practice (Figure 7-B, B2 loop). However, communities were unresponsive to these efforts, particularly as trust in government actors was low due to the absence of visible government investment in their communities.

\section{Addressing the Problem}

In response to the survey findings and considering the grave health consequences, the federal government commissioned environmental sanitation pilot projects in mid-1968. Through these pilot projects, the intention was to achieve safe water supply, sanitary disposal of excreta using sanitary latrines, safe disposal of solid waste and sullage, and improvement of the general cleanliness of the village environment. The pilot projects had four basic elements: community participation, health education, appropriate technology and training.

However, there was a strong paradigm that infrastructure work was outside MoH's mission of healthcare delivery. This generated internal resistance to the additional work and external resistance sceptical of the ministry's endeavours. The initiative required an extensive change in mindset among health personnel. Training was prioritized for the health staff, mainly health inspectors and health overseers, and incorporated the four elements used in the pilot projects. The approach successfully overcame resistance as described in 


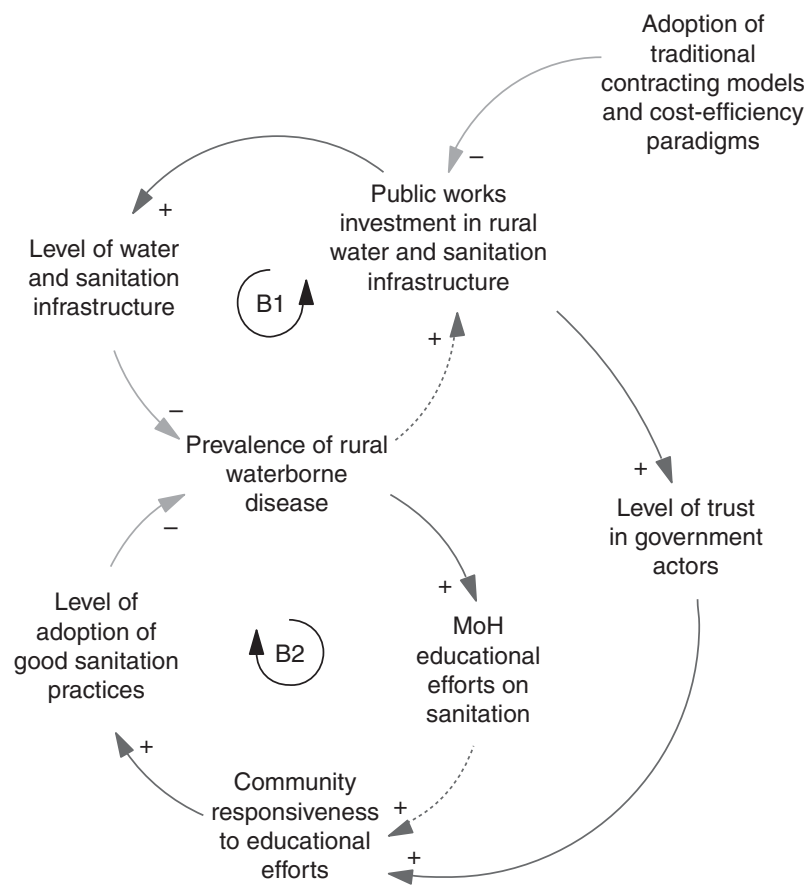

Figure 7-B Inadequate rural infrastructure investment in sanitation undermined community trust in government actors, hindering educational efforts that attempted to address the sanitation issues.

this case study, enabling scaling up of the programme, leading to the institutionalization of the National Rural Environmental Sanitation Programme by the federal government in 1973 under the mid-term review of the Second Malaysia Plan. This programme was later called the BAKAS programme or the Water Supply and Environmental Sanitation Programme (Pillay et al., n. d.).

\section{The BAKAS (Bekalan Air dan Kebersihan Alam Sekeliling) Approach}

Programme execution became the responsibility of the state public health departments, which provided funds and supplies to the various district health offices. At ground level, the district health officer, often assisted by the senior health inspector and health overseers, interacted with the village heads and village committees 
to organize health education, community participation and project initiation activities. State public health engineers provided technical input related to engineering (see Box 7-A for more details).

The communities responded with overwhelming support, with projects being executed within weeks of initiation. This success also encouraged many local politicians to lend their support and contribute to these community participation activities. State governments welcomed the programme initiated by the federal government and in time extended their full co-operation through their network of district administrative officers, who helped to identify needy communities and provided assistance to the district health officers.

By 2000, the coverage of rural households with safe water supplies was $93.5 \%$, and it was $98.2 \%$ for sanitary latrine coverage (Ministry

Box 7-A Details of the BAKAS approach

It was always clear from the onset that the technology utilized must be low-cost and appropriate. For sanitary latrines, the pour-flush toilet, which was connected to pits dug behind the toilets, was selected. Wherever available and feasible, small dams were constructed in hills, and water was piped to each household using PVC (polyvinyl chloride) and HDPE (high-density polyethylene) pipes. Each house was provided with one standpipe. Engineering surveys were done to ensure appropriate pressures were maintained. Open sanitary wells were constructed in areas with no hill sources; in other areas, tube wells were constructed and fitted with hand pumps or motor pumps.

The MoH supplied all materials needed, while the community provided the labour needed to instal the facilities. The villagers were also trained in maintaining these facilities. The villagers were repeatedly advised to boil the water before consumption. These small projects were completed within a few weeks and were a great relief for the communities, who had been waiting for a long time for a cleaner, more accessible water supply.

In summary, the key features that made BAKAS a success were the government's commitment to funding for all materials, the combined approach of addressing latrine construction and water supply, and the provision of technical staff with basic engineering knowledge, health education and training, while the community provided labour support and took ownership and undertook maintenance of the projects. 
Box 7-B Leadership and commitment of state public health engineers Pilot projects started with educational talks on the importance of clean water supply and sanitation and its impact on health. It was soon realized that these talks were insufficient to get the community to participate. An innovative move by a public health engineer - turning up at the house of the village head with all the materials required convinced the village head that this was not just more government propaganda and mere lip service. This led to the co-operation of the entire village. News soon spread, which led to local politicians coming on board and requesting similar projects to be set up in their constituencies. This single move led to a reversal of situations - instead of the MoH having to convince villagers of the need for water supply and sanitation facilities, the demand came from the villagers themselves, with a commitment to community participation. The results of the programme were gratifying, seen in the joyous faces of the rural population getting clean water on their doorsteps after years of waiting.

of Health Malaysia, 2002). This success could be attributed to leadership and commitment (see Box 7-B), available front-line health personnel who were based in the rural areas, the adoption of health as the paradigm for improved sanitation and water supply, and the four basic elements of the BAKAS programme. The mobilization of large numbers of auxiliary front-line staff in rural areas to engage local communities, supported by engineers with technical expertise, and enabled lower-cost solutions in which rural communities could participate and take ownership. This created rapid, cost-effective and locally sustainable solutions not possible under the traditional PWD approach, which relied on engaging contractors to construct large engineering projects (Figure 7-C).

The BAKAS programme was successful, and the delivery of infrastructure re-established trust in the government, enabling not only educational efforts on sanitation but also increasing responsiveness to other health initiatives. Apart from the low-cost water supply and sanitary latrines, other components were added, such as the disposal of solid waste and sullage water and the general cleanliness of the village environment. This programme complemented the other health programmes implemented at the district 


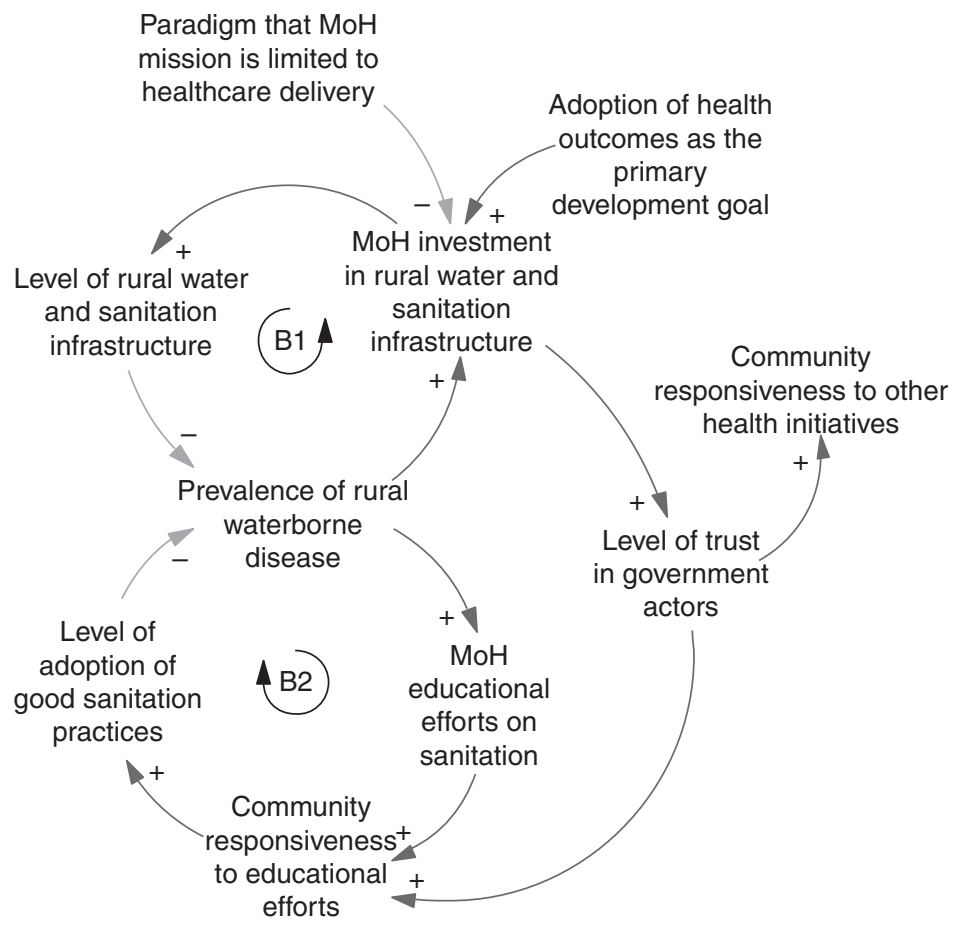

Figure 7-C The paradigm that the $\mathrm{MoH}$ mission is limited to healthcare delivery created internal and external barriers to its involvement in rural water and sanitation. However, once those barriers were overcome, its large personnel base and ability to prioritize health outcomes enabled community trust and responsiveness to rural water and sanitation interventions.

level, such as health education, communicable disease control, food hygiene and vector control.

\section{Systems Lessons}

Systems analysis illustrates that health authorities need to venture out of their traditional roles to address social and environment determinants of health. In this case study, the MoH had to undertake responsibility for rural water and sanitation, acquire engineering expertise, provide leadership to upgrade the basic engineering skills of front-line health workers, solicit community support, successfully convince the federal government to allocate the needed funds, and acquire administrative support from state governments 
and district officials. The analysis also highlights how a practical demonstration of government commitment can earn community trust and active partnership in environmental health initiatives.

\section{References}

Ministry of Health Malaysia. (2002). Annual Report 2000. Kuala Lumpur: Ministry of Health Malaysia.

Pillay, M. S., Sinha, I. K. and Mohd Talha, M. Z. (n.d.). Providing Reliable Drinking Water Supply to Remote Communities in Malaysia. Putrajaya: Ministry of Health Malaysia.

Suleiman, A. B. and Jegathesan, M. (eds.). (n.d.). Health in Malaysia: Achievements and Challenges. Ministry of Health, Malaysia.

System Analysis Case Study 7.2: Clinical Waste Management Debbie Siru, Mukundan Sugunan Pillay and David T. Tan

\section{Overview}

Careful handling of clinical waste is essential for mitigating adverse health and environmental consequences and is thus a crucial component of environmental health protection. While many governments recognize that integrating a systematic and multifaceted framework for clinical waste management into healthcare services is essential, this is often difficult to achieve because of competing priorities for limited government funding. This case study describes the strategies the Malaysian government adopted to achieve this.

\section{Background: The Problem}

Up until the 1980s, there was no proper system for managing clinical waste in Malaysia. With the emergence of HIV, the MoH revised the policies and guidelines for preventing and controlling infectious diseases to include clinical waste handling. However, these guidelines and policies only addressed the handling of waste at the hospital level, providing guidance on what categories of waste should be disinfected and how sharps should be handled. There were no comprehensive guidelines, policies or infrastructure for the 'cradle to grave' management of clinical waste.

Likewise, no department within the $\mathrm{MoH}$ took the lead to drive the many institutional and infrastructural changes required to ensure that clinical waste was properly managed. Thus each hospital managed 
clinical waste in its own fashion. Attempts at implementing piecemeal policies and guidelines on waste segregation were futile efforts, as waste was either burned in incineration kilns on hospital grounds or merely dumped in a hole in the ground and covered or burnt. In many other hospitals, clinical waste was simply discarded into the general waste stream and disposed of together with other solid waste in landfill dumpsites. Attempts by some more diligent personnel to segregate sharps saw innovative but ineffective use of all manner of non-puncture-proof containers, from used saline bottles to soda cans.

These poor levels of clinical waste management in hospital and clinic settings and the improper disposal of clinical waste created adverse societal and health outcomes, such as the misappropriation of used needles by drug users. Such incidents should have led to greater investment in resources and personnel for clinical waste management (Figure 7-a, B1 loop). However, the relevant investment was persistently inadequate due to limited resources, slow government processes and the high capital investment required for procuring the necessary facilities. Compounding this problem was the low priority hospital staff gave to clinical waste management. Assigned staff had other duties, and duties that directly related to patient care were routinely given priority at the expense of waste management duties.

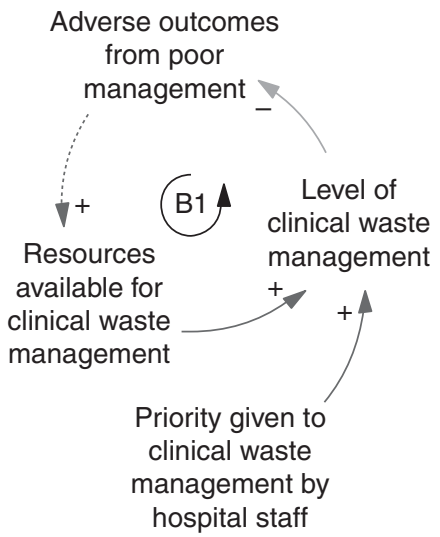

Figure 7-a Factors that led to poor clinical waste management. Limited government budgets prevented capital investment necessary for appropriate clinical waste management (dotted arrow). Adequate clinical waste management also requires prioritization by hospital staff; however, this was typically a low priority, with tasks directly related to the delivery of health services taking precedence. 


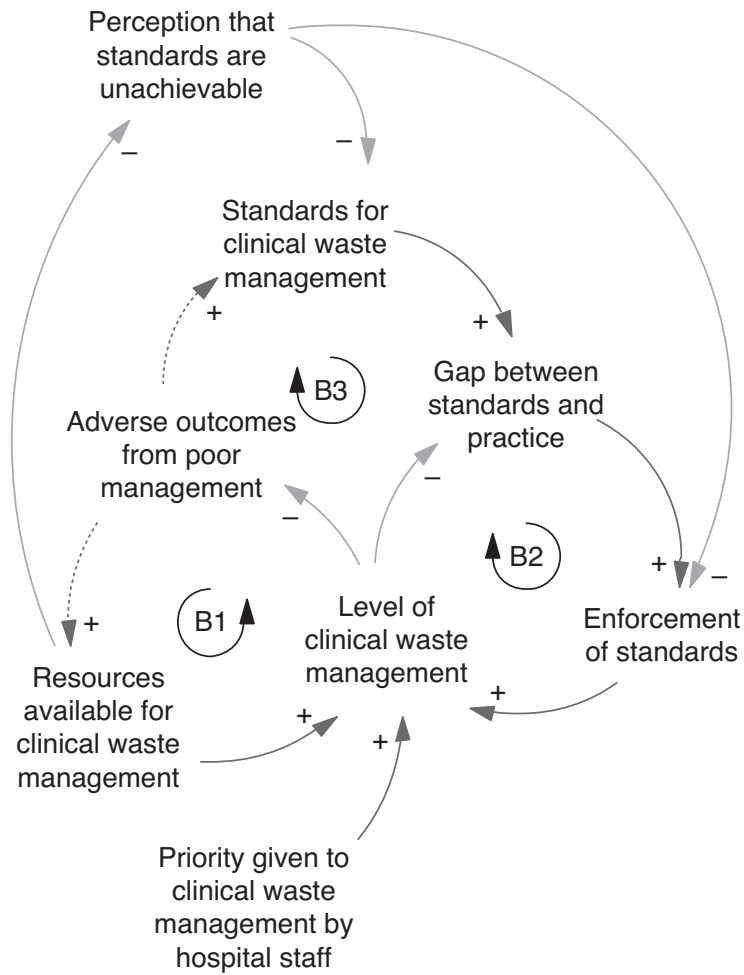

Figure 7-b Inability of the government to allocate sufficient resources for clinical waste management undercut both the enforcement of standards that did exist and the development of further standards necessary for 'cradle-tograve' management.

The unavailability of facilities, both within and outside of hospitals, necessary for complying with DOE legislation for clinical waste management created the paradigm that these standards were unachievable, rendering legislation unenforceable (Figure 7-b, B2 loop). Furthermore, the lack of forthcoming resources to address the existing shortcomings in practice made any efforts to improve on the existing $\mathrm{MoH}$ guidelines seem futile (Figure 7-b, B3 loop).

\section{Addressing the Problem}

While the $\mathrm{MoH}$ was aware of these problems, the financing bottleneck was a major barrier to any practical solution. The impetus for action finally arrived when the clinical waste problem entered public 
awareness through media reports of dogs scavenging body parts from hospital waste. Thus the $\mathrm{MoH}$ made the unprecedented decision to outsource clinical waste management. This was a controversial move that faced opposition from within the government and from large segments of the public and was possible only because of the urgency of the problem and a policy by the then prime minister on the privatization of government services.

Private investment in clinical waste infrastructure created the potential for the feedback loops that enable good clinical waste management to function properly (Figure 7-c). Indeed, the $\mathrm{MoH}$ took on the task of developing a set of detailed and comprehensive guidelines (Figure 7-c, B3 loop), including the Policy on Hospital Waste Management, the Guidelines for the Management of Clinical and Related Wastes in Hospitals and Healthcare Establishments, and the Action Plan for Waste Management in Hospitals and Healthcare Establishments, that identified the hospital's management responsibilities, the main components of clinical waste management and the protocols required. However, successful implementation required well-designed governance systems to create the right incentives for private sector contractors and hospital administrators, together with the information systems necessary to enable this. The details of the implementation are described in the following section.

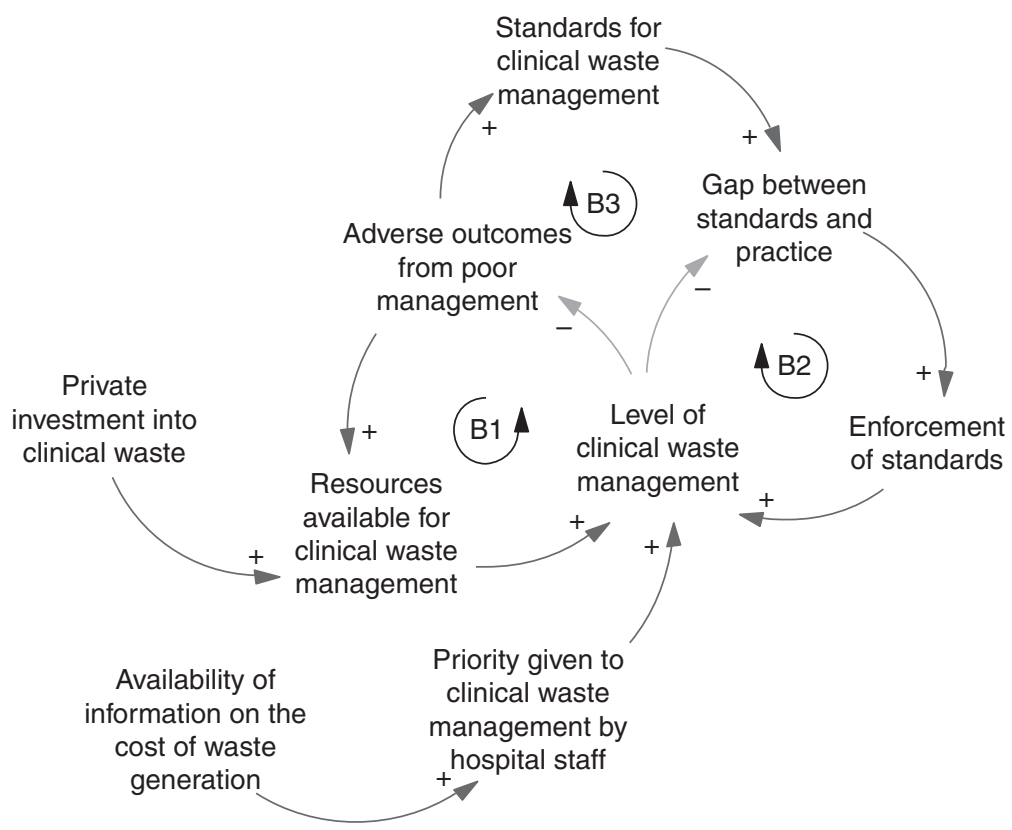


Caption for Figure 7-c (cont.)

Figure 7-c Outsourcing of clinical waste services enabled necessary capital investment for clinical waste management, enabling the B1, B2 and B3 loops to function properly. Well-designed governance and information systems were critical to successful implementation.

\section{Creation of the Outsourced Clinical Waste Management System (CWMS)}

Outsourcing (privatizing) what is essentially a component of healthcare services was unique and a paradigm shift, as it involved the private sector working in collaboration and in close proximity with the government sector. To ensure success, the following features and structure were incorporated:

\section{Financing and Development of CWMS}

- Capital costs were shifted to the private sector, removing the bottleneck, as operating costs were more easily approved in government budgetary process. Contracts with private sector operators (PSOs) locked in the amount the government had to appropriate for operating costs. This counteracted the tendency to underfund waste management.

- The private sector became responsible for the human resources, institutional development and infrastructure development required for a comprehensive CWMS. Thus the private sector was required to undertake all aspects of clinical waste management, with the exception of segregation. This also involved procuring the necessary equipment and vehicles for segregating, collecting and transporting waste to treatment facilities and constructing and maintaining storage and treatment facilities, as well as compliance with emission and all other environmental standards.

- The availability of resources overcame the perception that creating and enforcing standards would be futile - paving the way for the development and enforcement of guidelines complying with the 'cradle to grave' principle (see 'Creation of Standards'). 


\section{Assurance of Project Viability and Sustainability}

- To encourage private sector involvement, a fifteen-year contract was signed with selected PSOs. The long-term contract made it easier for the PSOs to secure financing. The amortization of capital costs over this period allowed for the determination of a reasonable and affordable service fee. The long-term contract also enabled the planning of upgrades and continuous improvement.

- At the time of signing the contract, a total of 127 existing $\mathrm{MoH}$ hospitals and institutions were included as part of the privatization package, with the potential for the addition of other new $\mathrm{MoH}$ hospitals in the future. This economy of scale not only benefited the PSOs but also meant that the service fee would be more affordable for the government.

- The fee structure based on Malaysian ringgit (MYR)/kg waste further ensured sustainability and profitability, as it was expected that the generation of clinical waste would increase with time, which proved to be true.

- To further ensure viability and sustainability, it was packaged with four other hospital support services as part of the privatization package: cleansing services, linen and laundry services, facilities engineering maintenance services and the biomedical engineering maintenance service.

- The PSOs were also allowed to generate additional revenue by extending their clinical waste management services to private hospitals.

\section{Non-monopoly}

- Based on experiences of other privatization exercises, the $\mathrm{MoH}$ awarded the privatization package to three companies instead of just one. This not only generated a healthy competitive environment for continuous improvement among the selected PSOs but also allowed the PSOs to utilize each other's treatment facilities in the event of shutdown for maintenance or other contingencies.

\section{Balancing Profitability and Public Good Service}

- While profitability was recognized as an important motivation for the private sector, the $\mathrm{MoH}$ ensured that its environmental health objectives would be met by: 
- Creation of standards: The privatization contract incorporated a detailed scope of works, procedures, performance indicators and standards:

- Technical Requirements and Performance Indicators (TRPI): Specify the scope of service and performance indicators.

- Master Agreed Procedures (MAP): Specify detailed procedures for the service.

- Quality assurance and implementation mechanisms:

- The privatization contract required PSOs to obtain the relevant certificates and licences, for example:

$\checkmark$ ISO 9001 certification.

$\checkmark$ Certificates of compliance with standards for bags and sharps containers.

$\checkmark$ Detailed EIAs for incinerator installation.

$\checkmark$ Compliance with various regulatory requirements and valid licences, for example, licence to operate incinerator, licence to transport waste, commercial vehicle licence, etc.

- In addition, the PSOs were required to develop the following for approval and implementation:

$\checkmark$ QAP: Sets out key performance indicators of the service at the zone and hospital levels.

$\checkmark$ Computerized central management information system (CMIS): Provides almost real-time data and information on various aspects of the service, such as waste generation, waste collection, waste consignment tracking, etc. The CMIS ${ }^{1}$ is also accessible anywhere and anytime with a secure ID and password.

$\checkmark$ Hospital-Specific Implementation Plan (HSIP): Details the operationalization of the TRPI and MAP at a specific hospital.

- Penalty mechanisms: To further ensure that services would be delivered to the required standards, the contract included the following:

- Deduction formula: Allows the MoH to deduct fees for nonperformance or unsatisfactory performance by the PSOs. The CMIS also incorporated a module for automatic capture of certain unsatisfactory performance, for example, non- 
compliance with collection and transportation schedules, validity of licences, emission standards, etc.

- Third-party clauses: Allow the MoH to engage alternative PSOs or other vendors in the event that any aspect of the service is not delivered in a timely manner.

$\circ$ Monitoring and auditing mechanisms:

- A regulatory unit was set up within the $\mathrm{MoH}$ to monitor and enforce the contractual requirements.

- This unit was assisted by a third-party consulting company. In addition to verifying the accuracy of the CMIS data, these consultants monitored aspects of the service that could not be captured in the CMIS, for example, correct procedures and supply of correct receptacles for segregation. They also advised hospital staff on their roles and responsibilities on verifying the work by the PSOs as well as various aspects of the service.

The transformation brought about by privatization is summarized in Table 7-A. Apart from this transformation, privatization yielded information and resulted in accountability. The cost of waste management, which was previously hidden (e.g. by tasking hospital staff with clean-up responsibilities in addition to other duties), became clear. Paying the private sector per kilogram of waste also incentivized the system to reduce waste generation. Payment for services to a third party also created the rationale for a monitoring system to hold contractors and hospitals accountable to the $\mathrm{MoH}$. For the first time too, data on waste generation was available to provide information on status and to enable the assessment and planning of future needs.

Table 7-A Comparison of scope of services before and after privatization

\begin{tabular}{llll} 
No. & Scope of services & $\begin{array}{l}\text { Before } \\
\text { privatization }\end{array}$ & $\begin{array}{l}\text { After } \\
\text { privatization }\end{array}$ \\
\hline $\begin{array}{l}\text { 1. } \\
\text { Yellow bags for non-sharps } \\
\text { clinical waste }\end{array}$ & No & Yes \\
$\begin{array}{c}\text { Blue bags for autoclaving microbiological } \\
\text { waste }\end{array}$ & No & Yes \\
3. $\quad \begin{array}{c}\text { Dedicated waste receptacles with } \\
\text { lids and pedals to hold bags }\end{array}$ & No & Yes \\
4. Sharps containers for sharps segregation & Partial & Yes
\end{tabular}


Table 7-A (cont.)

\begin{tabular}{|c|c|c|c|}
\hline No. & Scope of services & $\begin{array}{l}\text { Before } \\
\text { privatization }\end{array}$ & $\begin{array}{l}\text { After } \\
\text { privatization }\end{array}$ \\
\hline 5. & $\begin{array}{l}\text { Dedicated collection containers } \\
\text { and trolleys }\end{array}$ & No & Yes \\
\hline 6. & $\begin{array}{l}\text { Dedicated vehicles for waste } \\
\text { transportation }\end{array}$ & No & Yes \\
\hline 7. & $\begin{array}{l}\text { Regular washing and disinfection } \\
\text { of receptacles and trolleys }\end{array}$ & No & Yes \\
\hline 8. & $\begin{array}{l}\text { Secured and covered stores, refrigerated if } \\
\text { necessary }\end{array}$ & No & Yes \\
\hline 9. & $\begin{array}{l}\text { Washing facilities at store with } \\
\text { connection to sewers }\end{array}$ & No & Yes \\
\hline 10. & $\begin{array}{l}\text { Tagging and identification: date, time and } \\
\text { source of generation }\end{array}$ & No & Yes \\
\hline 11. & Personal protective equipment & No & Yes \\
\hline 12. & $\begin{array}{l}\text { Collection and transportation schedules: } \\
\text { frequency and time }\end{array}$ & Partial & Yes \\
\hline 13. & $\begin{array}{l}\text { Weighing of waste and consignment note } \\
\text { system for 'cradle to grave' waste } \\
\text { tracking }\end{array}$ & No & Yes \\
\hline 14. & $\begin{array}{l}\text { Clinical waste incinerators with air } \\
\text { pollution controls, stores, washing } \\
\text { facilities, etc. }\end{array}$ & No & Yes \\
\hline 15. & $\begin{array}{l}\text { Continuous emission monitoring for } \\
\text { selected parameters }\end{array}$ & No & Yes \\
\hline 16. & $\begin{array}{l}\text { Ash disposal at secured hazardous waste } \\
\text { disposal sites }\end{array}$ & No & Yes \\
\hline 17. & $\begin{array}{l}\text { Compliance with all other regulatory } \\
\text { requirements and valid certificates and } \\
\text { licences }\end{array}$ & No & Yes \\
\hline 18. & Computerized data management system & No & Yes \\
\hline
\end{tabular}

\section{Other Benefits of Privatization}

The knock-on effect of the CWMS outsourcing is the development of local industry and competency. Examples include:

1. Manufacturing industry: Clinical waste bags, on-site storage receptacles and sharps containers imported at the start of the privatization 
exercise are now locally manufactured and conform to international standards.

2. Laboratory services: The DOE requirement for incinerators to comply with various environmental standards, for example, effluent, air emissions, ambient air and noise standards as well as incinerator performance standards, have created opportunities for local laboratories. The increased demand for such testing services has also spurred the development of local competency. Dioxin and furan sampling and testing capability, which were once sourced from foreign laboratories, are now locally available. This has in turn resulted in savings in testing costs and foreign exchange.

3. Human resource development and job opportunities: Approximately 2,300 personnel employed by the $\mathrm{MoH}$ were absorbed by the companies under the privatization exercise. Staff strength has increased since then to more than 10,000, with approximately 2,000 people directly employed for the outsourced CWMS. In addition to these job opportunities was the development of skills and expertise among personnel.

4. Export of expertise and services: The development of local competency within the government and private sector has now put Malaysia in a position where its services and expertise are exportable.

5. Expansion of privatization scope: The scope of waste management has been expanded to include all other hazardous wastes in hospitals, such as chemical waste.

\section{Challenges}

As with any project, especially one that has never been attempted before, there were challenges. Examples encountered at the hospital level included:

1. Changing the mindset of hospital personnel, for example:

- Discarding waste without segregation had to be unlearned.

- Unrealistic expectations that, with privatization, hospital personnel were absolved of all responsibilities relating to clinical waste management. Thus verification of waste collection, weighing of waste, etc. were considered as competing with their core responsibilities, that is, patient care. 
- Hospitals are typically space-constrained, hence there was reluctance to give up what was considered valuable space for the placement of dedicated clinical waste receptacles.

2. Some hospital personnel made unwarranted and impractical demands in the name of infection control. Examples are:

- Requiring collection to be done three times a day even from wards or departments that generated only small amounts of clinical waste.

- Not allowing the use of service lifts for collection trolleys.

3. Misuse of equipment and services by hospital personnel.

- As the bags and sharps containers were of high quality, hospital personnel found other incorrect uses for these, for example, storing tissue samples.

- Discarding other hazardous waste into the clinical waste stream.

4. Non-compliance by PSO personnel.

- Poor verification by hospital personnel led to some noncompliance with schedules, and these non-compliances were not accurately captured in the CMIS.

- Aspects of the service that could not be captured in the CMIS were sometimes not complied with, for example, collection procedures, receptacle-washing procedures, etc.

5. Ambiguous standards and incorrect interpretation of standards. Some aspects of clinical waste management were not sufficiently detailed in the MAP, while some were ambiguous, leading to incorrect and non-uniform practices.

These challenges were overcome via:

1. User training by the PSOs, which was a requirement in the privatization contract.

2. Audits by the $\mathrm{MoH}$ regulatory unit as well as audits and training by the third-party consultant engaged by the $\mathrm{MoH}$.

3. Development of guidelines by the third-party consultant.

At the regional level, there were delays on a few occasions by a PSO to:

1. Repair or upgrade air pollution controls, leading to shutdown of the incinerator by the DOE. 
2. Upgrade the incineration capacity or instal additional facilities to meet increasing clinical waste generation, leading to a pile-up of clinical waste at the treatment facility and hospitals.

One factor contributing to the delay was the difficulty in finding suitable sites for the installation of an incinerator due to different priorities of different government agencies and land-zoning issues at the local municipal level. The lack of commitment by new company shareholders in investing was another possibility. Thus the initial suggestion for the contract to stipulate a minimum period of the shareholding of the PSO should have been considered.

The non-monopoly strategy was keenly realized as an advantage during these times, as the other PSOs were able to assist. Realizing the need to resolve this problem, the DOE also relaxed the licence conditions, enabling the PSOs to transfer waste to other treatment facilities during this period.

\section{Systems Lessons}

Systems analysis demonstrates how inadequate financial resources could create and sustain several interconnected vicious circles of poor management and negative attitudes, resulting in poor health outcomes. A hitherto untried approach of mobilizing private sector funding converted the vicious circles into virtuous ones.

While privatization through outsourcing may not be the solution for every country, it seems clear that this was the right path to take in Malaysia. The experience gained from 15 years of implementation enabled the $\mathrm{MoH}$ and its consultants to refine the system further to improve the efficacy of service delivery. It has been 22 years since clinical waste management was first privatized, and Malaysia has a system that remains functional and with an expanded scope that covers other types of healthcare waste. Enforcement by the DOE in private hospitals and clinics is also possible now. Thus potential health risks are not only minimized but a potentially massive and expensive environmental clean-up has been averted, which would have been required if the pre-privatization situation had been allowed to continue. 


\section{References}

Borongan, G., Siru, D. and Hassan, M. N. (2015). Review on the status of healthcare waste management in selected countries of the Western Pacific Region. Journal of the Indian Society of Hospital Waste Management, 13\&14(1), 22-41.

Pillay, M. S. (June 1999). Privatization of Support Services in Medical and Healthcare Setting: Evaluation and Cost Implication. Proceedings of the Directors' Conference 1999, Ministry of Health Malaysia.

Siru, D., Pillay, M. S. and Sinha, K. (2006a). A national approach to clinical waste management. Journal of Solid Waste Technology and Management, 32(4), 199-205.

Siru, D., Pillay, M. S. and Sinha, K. (February 2006b). Health Care Waste Management in Malaysia. Proceedings of the International Seminar on New Trends in Hazardous and Medical Waste Management.

Siru, D., Pillay, M. S. and Sinha, K. (February 2006c). Health Care Waste Management in Malaysia. Proceedings of the International Workshop on Reasons and Remedies for Sustainable Healthcare Waste Management.

World Health Organization. (2015). Status of Health-Care Waste Management in Selected Countries of the Western Pacific Region. Geneva: World Health Organization.

\section{Note}

1 This has since been upgraded and is now called the Asset and Services Information System (ASIS). 